\title{
The everyday of people waiting for kidney transplantation*
}

\author{
0 cotidiano da pessoa à espera do transplante renal
}

Micheli Rezende Ferreira $\mathrm{Cruz}^{1}$, Anna Maria de Oliveira Salimena ${ }^{1}$, Ivis Emília de Oliveira Souza ${ }^{2}$, Maria Carmen Simões Cardoso de Melo ${ }^{1}$

Objective: to understand the everyday of people experiencing the waiting list for kidney transplantation. Methods: this is a qualitative research, based on Heideggerian phenomenology. 14 deponents participated in hemodialysis and registered on the waiting list for kidney transplantation. Phenomenological interview with the research question: How is the experience awaiting the kidney transplant? Color marking technique for analyzing demarcating lines that show similarity, of these, emerged the essential structures that enabled the units of meaning. Results: changing lifestyles, imposing a routine and rigidity of treatment signaling everyday stress and exhaustion of hemodialysis being. Emerging from the modes of gossip, curiosity, and bureaucracy, unfolding-inauthentic and impersonal regarding their care. Conclusion: hemodialysis dependence and awaiting kidney transplantation transfer care for family/professional caregivers. To understand the everyday marked by impositions and restrictions, the reflection about how professional health interaction/being-care becomes important.

Descriptors: Waiting Lists; Kidney Transplantation; Renal Dialysis; Qualitative Research; Nursing.

Objetivo: compreender o cotidiano da pessoa na vivência da lista de espera para o transplante renal. Métodos: pesquisa qualitativa, embasada na fenomenologia Heideggeriana. Participaram 14 depoentes em hemodiálise e cadastrados na lista de espera para o transplante renal. Entrevista fenomenológica com questão norteadora: Como é a vivência na espera do transplante renal? Análise pela técnica de marcação de cores demarcando falas que apresentam similaridade, destas emergiram as estruturas essenciais que possibilitaram as unidades de significado. Resultados: mudança dos hábitos de vida, imposição de uma rotina e rigidez do tratamento sinalizando tensão cotidiana e esgotamento do ser-hemodialítico. Emergindo os modos da tagarelice, curiosidade e burocracia, desvelando-se inautêntico e impessoal no que tange ao cuidado de si. Conclusão: dependência da hemodiálise e aguardar o transplante renal transferem o cuidado para a família/profissionais de saúde. Compreender o cotidiano marcado por imposições e restrições, a reflexão sobre o modo de interação profissional-de-saúde/ser-cuidado torna-se importante.

Descritores: Listas de Espera; Transplante Renal; Diálise Renal; Pesquisa Qualitativa; Enfermagem.

\footnotetext{
*Extracted from the dissertation "O sentido do ser-portador-de-doença-renal-crônica-na-vivência-da-espera-de-um-novo-rim: contribuição da enfermagem para o cuidado em saúde”, Universidade Federal de Juiz de Fora, 2014.

${ }^{1}$ Universidade Federal de Juiz de Fora. Juiz de Fora, MG, Brazil.

${ }^{2}$ Universidade Federal do Rio de Janeiro. Rio de Janeiro, RJ, Brazil.

Corresponding author: Micheli Rezende Ferreira Cruz

Rua Halfeld, 1097, CEP: 36016-000. Centro - Juiz de Fora, MG, Brazil. E-mail: mijfrezende@ig.com.br
} 


\section{Introduction}

The definition of Chronic Kidney Disease corresponds to the injury of the renal parenchyma with normal function and/or decreased present for an equal period or superior to three months. The staging and classification are determined by Glomerular Filtration Risk (GFR) in which: Stage I, GFR $\geq 90 \mathrm{~mL} /$ minute with renal injury (for example: proteinuria); Stage II, GFR between 60 and $89 \mathrm{~mL} /$ min; Stage III, GFR between 30 and $59 \mathrm{ml} / \mathrm{min}$; Stage IV, GFR between 15 and $29 \mathrm{~mL} / \mathrm{min}$ (initial uremic signs); Stage $\mathrm{V}$, GFR $<$ than $15 \mathrm{~mL} / \mathrm{min}$, total loss of renal function is irreversible and has severe uremia (recourse to dialysis treatment) ${ }^{(1-2)}$.

Stage $\mathrm{V}$ is characterized by the imbalance of the internal environment of the kidneys with the appearance of metabolic disorders, endocrine, electrolyte and basic acids. The main signs and warning signs are: nocturia, high blood pressure, weakness, anemia and swelling of the face and lower $\operatorname{limbs}^{(3)}$.

To maintain the life of people with chronic kidney disease and alleviate the symptoms of the disease, renal replacement therapies were developed, such as hemodialysis, peritoneal dialysis and kidney transplantation ${ }^{(4)}$. The selection and/ or modification regarding the therapy are guided by demographic, individual and pathological features such as association with co-morbidities, severity and evolution ${ }^{(5)}$.

The hemodialysis is the most used treatment and represents the continuity of life, but for this determines the person to physiological dependence on hemodialysis machine to debug the blood, partially replacing renal function ${ }^{(5-6)}$.

The transplant has a better quality of life and survival for individuals but has the difficulty of long stay of the person on the waiting list for the procedure. This fact occurs by the existence of more entries than the organs supply, which causes long waiting time to perform kidney transplantation ${ }^{(7-8)}$.
It is observed that people with chronic kidney disease have different ways of dealing with the disease and its treatment. But in general, at some point, they bring emotional conflicts and traumatic and/or complex experiences that can change their everyday life and generate a significant impact on quality of life $^{(9-10)}$.

Everyday life is observed by day-to-day life of people and also as part of the social scheme of an individual, where analyzes the "being" within its life context ${ }^{(11)}$. In the search for a different view of everyday relationships and the quality of life of hemodialysis people, we used the phenomenology as a theoretical, philosophical and methodological framework.

The research indicates an understanding of the following concerns: the view that the person has with chronic kidney disease, about its limitations and complications of their health and their experience to be on the waiting list for kidney transplantation. And then, it became an objective of this research to understand the everyday experience of people on the waiting list for kidney transplantation. With the following guiding question: How do you experience waiting for the kidney transplant?

This research emerged to understand the difficulties faced by people on hemodialysis to reflect about the disease, proper treatment, and questioning to the limitation imposed on their everyday lives, but also the need for dissemination and discussion of the everyday routine of these people.

Due to the concerns already described, the use of the phenomenological approach was justified, in the light of the Heideggerian framework, to seek to understand the everyday people experiences on the waiting list for kidney transplantation.

\section{Methods}

Qualitative research, based on the phenomenological approach of Martin Heidegger who seeks to understand the way that the person with chronic kidney disease has on everyday hemodialysis 
and waiting for a kidney transplant, against the backdrop of a clinic for renal replacement therapy, based on the Mata Mineira zone.

The clinic serves 165 people on dialysis, 59 were on the waiting list for kidney transplantation in the data collection period. The change in the types of treatment led to the exclusion of fifth-teen people; eleven went for peritoneal dialysis and four underwent transplantation. The selection of participants was through the listing of the waiting list for kidney transplant recipients undergoing hemodialysis. The participants were 14 people registered on the waiting list for hemodialysis kidney transplant, eleven women, and three men.

Inclusion criteria: users aged 18 to 60 years old; registered in the single list for kidney transplant of the renal replacement therapy clinic; and hemodialysis. The exclusion criteria: people who have already performed a kidney transplant with rejection; people treated by peritoneal dialysis.

In the renal replacement therapies clinic, we contacted active people on the waiting list for a kidney transplant, and when accepted to participate, they could choose a comfortable place to conduct the interview. The interviewees chose the time of hemodialysis sessions; they said it would be an entertaining way to spend faster the time they were in treatment. Marked the day of data collection, the interview began only after reading and signing the Informed Consent Form.

Data collection was through an open interview for allowing a free language, we use a script as a tool, containing the guiding question of research and a field diary to record the non-verbal language, expressed in gestures or other events.

The interviews were recorded in MP4 and held at once, by seeking to understand the moment experienced by the person. The collection period was between the months of October/2012 to April/2013. Concerning the choice of the participants, the months of December (2012), January and February (2013) were excluded from conducting the interviews, they expressed that were the months that they felt more sad and depressed by the commemorative celebrations and school holidays. Some interviews were rescheduled because of complications during hemodialysis sessions. Such limitations have generated a gap in the data collection time. The interviews lasted around 42 minutes to 1 hour and 10 minutes. Participants chose fictitious names of precious stones, preserving their identities.

In the field stage was first developed the ambiance for an approximation with the likely research subjects and to observe the everyday life and its features. It comprised a period of 15 days. The observation was to monitor day-by-day these people in hemodialysis clinic and the conviviality of the group among themselves and with health professionals. Allowed to accompany moments of sadness, joy, anger, among others. After this period we performed the phenomenological interviews and subsequently, every testimony registered information relevant to the field diary. Here, the observation of non-verbal communication through gestures and expressions performed during the interview, if was converging/ diverging with what was said.

The interviews were fully transcribed and analyzed after each meeting. To determine the meaning units, we used the marking technique with color demarcating the lines approaching an axis. The collection was interrupted when the testimony did not add more value to the knowledge of the object because each unit of meaning already presented the statement of the majority of the interviewees. The statements become similar and with the same response content. The research saturation point is grounded by the theoretical approach and by the objective of the research $^{(12-14)}$.

The organization of data occurred in the analysis, in an attempt to group the reports that had similarities, and from these emerged the essential structures that allowed the development of units of meaning ${ }^{(13)}$.

The analysis of the Heideggerian method is 
grounded for two moments, which are: a vague and median understanding ( $1^{\text {st }}$ time) which seeks to understand the everyday facts by its description, is what the entity shows directly and most of the time, for everyone (ontic dimension); and interpretive or hermeneutic understanding $\left(2^{\text {nd }}\right.$ time) tries to unveil the phenomenon (ontological dimension) that presents obscure in the description of the facts, the question of being is necessary (who unknown) ${ }^{(15)}$.

The study complied with the formal requirements contained in the national and international standards of regulatory research involving human subjects.

\section{Results}

The essential structures were organized in meaning units which include the vague and median understanding. This understanding has meant:

\section{Modification of life habits}

They express that their lives are governed by the routine of hemodialysis sessions that take place three times a week for four hours each/day and the obligation to go to the clinic for treatment in the hemodialysis machine and the procedures such as puncture of the arteriovenous fistula.

They highlight the food and liquid restrictions describing the difficulty in changing their habits, feel the desire to drink liquids and when they do not resist thirst are concerned with increasing weight and the possibility of dying. As the following statements: It's horrible, too bad, because four hours here three times a week. I say that is not for anyone! Here we get very limited, and we have to come, we have to connect, we have a large restriction of food, drinking water (pause). You can not travel quiet, insecure because you have to mark where you go to do hemodialysis (Topaz). I was very angry, and I did not accept too much, but now I'm accepting. What can I do? You have to accept (hemodialysis) and wait (the transplant). At the beginning it was not good, not now either, I do not think is good to leave home and stay here. Is not good nailing needle and everyday have restrictions, and I feel sick. You also can not eat, drink plenty of water, and it changes a lot (Aquamarine). I still consume liquid. Water, I can not stop! I can not stay without it, for me it's difficult. But if you do not change, there is no way. I already got a weight of $4.5 \mathrm{~kg}$ ! I could die even sleeping, so much water, I cannot sleep the night because I am worried (Citrine).

The person in hemodialysis shows the need to adapt to new conditions and for this, they use different ways of coping to deal with changes in their everyday lives. The experience of each one about their health can be varied according to the influence of various factors such as their physical, psychological, socialcultural condition and life history.

\section{Imposition of a routine}

Chronic disease issues such as difficulty walking, pain, swelling, weight gain and reduction/loss of urinary elimination improve with the completion of hemodialysis. So they report that the body "feels" when do not go to sessions, they have difficulty walking and headache imposing realization and dependence of therapy. As evidenced by: Occasionally, I feel sick, I have cramp and pressure, but is not always hemodialysis, it is the disease. Ah! Strange, yes, but the tendency is you try to improve if I accept the machine is to try to improve. As I am talking about: is not good, but the hope is to improve. But there is not much improvement because it will always stay at this rhythm there (in hemodialysis). Only if you transplant, but the treatment you will never be free (Quartz). At first, I could not walk, much pain, swelling and weight. To improve you need to do treatment. The problem is not only the weight if it were only water it was good, but the body feels, to walk, headache, stop working and stay at home, change in life. Like today, I was two days without coming and last night I was crazy to come. I could not wait to get here to improve when you take a weight is bad, and the body get used to the machine (Citrus). About this here, you miss it, when it comes Saturday and Sunday we miss it (laughs). It is to be adapted. Adapted, ok?! (Diamond).

They report a lack of freedom, especially related to the realization of trips longer than two days or to places that do not have a dialysis center, showing the dependence of hemodialysis machine and the 
health team: So you have to have an orderly life, can not go out, you have chronic issues and have to come to the clinic. I'm afraid, I have the fistula problem, the puncture does not always work, the girls here already know. Then if I went out and caught a person who does not know? Do you understood?! (Diamond). Ah! It should be very good, first to leave from here, and (pause) a normal life, traveling, sightseeing. I have nieces who live outside the country, and I can not visit. Then (pause) I tell you that is not easy. It's difficult. That's when I see that time passes, but it is (pause) trusting God, always (Alexandrite). To come here (hemodialysis clinic) was a struggle. To look at this machine, I took two hours to look it and see the blood passing through it. It's horrible, very bad. Now, I have to live right! I have to live with it. As they say, this is a routine now, right?. It became a routine. Here we get very limited, and you have to come (Topaz).

They were concerned with the completion of hemodialysis and transportation to the clinic because they express the difficulty of locomotion because of the symptoms of the disease and the time it takes to perform the way to the dialysis center. Expressed in the words: The bad thing is leaving home (live in another city), is transport. So stay here four hours is achy (crying). It is an option that I have, but for me is bad, I'm tired of having to do this (Rubi). When I come here I leave three o'clock and a bit, and I have to leave in the morning and here time goes by, and I stay up late. Then I feel worried, and I feel sad and very troubled. But then I said, wait! Getting desperate? I now saw an opportunity (Turquoise). Some days I arrive early and some days I arrive late at home, it changes everything. And I need to do it right (hemodialysis), you have to do. Can not staying at home. Work is difficult, but the treatment here is good. And if you have a serious and difficult problem they solve it (Citrus).

Hemodialysis determines the person to physiological dependence on the dialysis machine to debug the blood, partially replacing renal function, relieving the symptoms of the disease and consequently prolonging life. But at the same time, it brings restrictions and a significant impact on its quality, as changes in their social interaction, in leisure activities and tour of the frequency of sessions.

\section{Treatment stiffness}

They express that exist anxiety about the prediction of the duration of the hemodialysis caused by signs and symptoms of the treatment, such as cramps, (hyper) hypotension, malaise, dizziness, increased heart rate and shortness of breath. But also by the instability of control of their health. As the following reports: I do not think is good to leave home, come here three times a week and they nail the needle (expression of pain and shows the fistula). My pressure goes down, and I feel sick. Every day has restriction, and I feel sick, isn't it?! It's bad, and it changes a lot (Aquamarine). It's too bad, there are days that are good, and there are times when it is not okay. At the same time, you are talking you are feeling sick. Sometimes the pressure is good and then goes down. Sometimes I'm sick in the middle of the session, or the pressure goes down too much, and I do not see anything, or sometimes the pressure rises. Two times my heart raced a lot, I had to get oxygen. Some days I arrive home doing nothing of hemodialysis, quiet but sometimes I arrive, and I need to rest at least two hours to pass. But it is this everyday (pause) I cannot explain, I can't (Topaz). Not now (in hemodialysis), now that I understand (how sessions are) we feel like this (pause) begins to cramp, I just stand for three hours. Only three hours to feel good, then my blood pressure goes down a lot and has a lot of cramps (Alexandrite).

There is the need for compliance with the shifts and hemodialysis times, but the effects of the treatment sessions can be unexpected, which has implications for their health status and can cause emotional conflicts.

\section{Important aspects of everyday change}

They show difficulty or impossibility of labor activities by having to perform weekly sessions and by presenting physical inactivity. They express that their activities are restricted to domestic activities, and depending on their post-session state they can not perform them. Thus, worsening the physical aspects and the use of therapy changes the lives of these people, by the commitment in activities and leisure by fatigue, dejection, and malaise, reporting that life ends: I'm afraid of hemodialysis! From one day to the other I was here. Then you can not work anymore, and I can not. I moved here with my family, and it changed a lot, it changed a lot. Then I think 
a lot right! You have to be strong. Because I want to live and live longer (Opal). I have always worked, and I liked to work, and now I depend on others. What I want is to get back to work (laughs). Work is important to me. It's good, and I would be happy. I fight to improve, and I came to hemodialysis (Sapphire). Very difficult, treatment is very difficult. Life has changed, changed completely. It was active and now getting used not working is difficult. Now I just do something or do not do anything, just at home. The treatment is the way of life, can not urinate, you have to come here and can not miss (Citrus). Oh! My life changed everything. I was used to working and walking. Now I'm at home, just stay at home. I can not do anything else, it's over (pause) life ends. You get dependent on it (Hemodialysis) (Quartz).

There is also decreased of the social interaction regarding the habit changing not moving from their home in shame of the disease and discouragement to explain the treatment. But mostly, by changing their image after making the arterial fistula and central venous catheter. What makes your mobility be restricted to hemodialysis sessions. They express: Too bad. Because I had to put the catheter in the neck, then left my house, only to come here. I only went out from home to here and here to home. I don't go out because I'm ashamed, and people ask me, what is this? (shows the arteriovenous fistula) To come here is a struggle. To look at the machine, to look at it, to see the blood passing through it (Topaz). Only to make dialysis and the fistula I take one month. A lot of things is to survive, so I stay here (hemodialysis clinic) and with this (fistula). But I am worried. What is very bad is this, oh! Fistula, I feel bad and just stay at home (Turquoise). I have prejudice, but I have to live right! I have to live with this (fistula) and with the routine now. It became one (Aquamarine).

They speak about the influence of psychological aspects in the regular changes, showing jolt and emotional fragility not doing the same things with the chronic disease. They report discouragement, depression, crying and negative ideas about the maintenance of life. They marked that: Hemodialysis is to survive. But you have to stay here. It is an option that I have, but for me, it does not work, because at home I have a lot, for me it does not work. Everything changes. Mainly, the personal life. I do not do the same things I did before getting sick. I have no heart for anything, and the emotional is a mess right?. So I do not like to go out (Rubi). I was always crying, being honest (pause) I wanted to take poison, lived tremendously, had depression, I did not die because God is very good (Sapphire). Staying well is going out of here. I have a friend who did, and he is well, he can go out and work. We see that may have (pause) can be fine, especially drinking water. It's a hard life to have and not have. Huh! And so everything has its time (Esmeralda).

The dependence on others as family, regarding financial and emotional factors. The health team regarding the bond created in providing services and carrying out procedures such as dressings and puncture the arterial fistula. And with the other carriers of the disease by supporting the sessions with the use of jokes and conversations. Once identified: So (pause). I do not like to see the hurt. They are usually (nursing staff) who know how to do this part, but do not see because I turn my face. Then, I don't like it. Oh! The fistula and cramp. But here I am treated very well, if I die, and I know that I was well treated. Here everything is all right, sometimes we buzz with the other, then they said: take it easy. We joke and that's how we survive (Turquoise). I am afraid. Treatment is something that makes me feel very bad. You arrive home and feel like an animal, then get used to it. Our mother! It is very sad because you do not know everything. I think that happens a lot of things here, and we do not know. Very frustrating, I did not cry and did not do anything, because I had my daughters support, but they wrestle a lot. They are very angry with the disease and despair (Diamond). I was nervous, did not talk, talking to anyone here. I was very sad. I have always worked, and now I depend on others. My sister lives with me, and I come to live with her. There are times that I can help, and there are times that you can not (Sapphire).

Speaking about their everyday lives, they describe the decline of routine or work activities, as well as the reduction in social life, having a significant impact on their quality of life. Negative emotional factors are present to express their day-to-day hemodialysis, showing psychological instability and dependence on family and health team.

\section{Discussion}

The study reveals how people with chronic kidney disease include, in their subjectivity, their possibilities of experiencing the waiting list for kidney transplantation. It points to the importance 
of understanding the everyday lives of these people and to this end, and as hemodialysis constitutes a fundamental element because the day-by-day life is influenced by the events of the treatment sessions. The way as these people describe their experience suggests inauthenticity and impersonality of their care, highlighting the dependence on hemodialysis and passivity to wait for a kidney transplant. For Heidegger, the critical interpretation of the study results is the second moment, in the hermeneutic understanding, which seeks to understand unveiled aspects of the phenomenon.

The performance of the research in a single institution configures as the study limitations, to be specific to one area. The realization of the interview using hemodialysis sessions generated interrupts, in some cases, reducing privacy between researcher and interviewee.

To emerge the concept to be announced in the way of being hemodialysis in the list waiting for the transplant, indicates everyday, "whose way of being the first contact is determined by the existence of Dasein in contact with its public coexistence"(14:460-1), that is, for the most part, is immersed in the day-byday of their everyday lives and expresses the behaviors expected by society and the inserted group.

As in other studies, the everyday is manifest: by the hemodialysis routine and by physical problems expressed by swelling, fatigue, shortness of breath, high blood pressure, cramps and numbness in the lower limbs, severe pain, etc. The day-by-day permeated by feelings of sadness, worry, annoyance, anger, stress and tension with hemodialysis treatment ${ }^{(11)}$.

Hemodialysis provides their survival, but also brings physical and emotional problems. They declare that there is a sense of gain and loss in their life, which is in a constant struggle to routine hemodialysis and seeking to improve their health. The being is exposed to everyday life without choices, absorbed by the world and in the public domain, in which constitutes the hemodialysis routine. "Being in everyday life without realizing that is surrounded by it" ${ }^{\prime(14: 184)}$. Being similar to that observed in another study ${ }^{(10)}$ that points dependence on hemodialysis and the need to adapt the individual, being a complex process that mobilizes everyday life the obligation to accept treatment as the only way of survival.

Then, they do not realize dominated by everyday and always repeating the same things. They design to being healthy again, showing impersonality and inauthenticity, where the health context dictates the rules and the situation are dominated by the clinical context of day-by-day and understanding becomes a group and not an individual.

In everyday life the being-there is in the day-by-day factual, being released in decay, that "constitutes a particular way of being in the world that is totally absorbed by the "world" and the co-presence of others in the impersonal" (14:237). Involved in the occupation of their routine, existing in its factuality thrown into the world without the possibility of choices, because he does not understand who he is (ensuring the sense of being), but considers that has a chronic and fatal disease and untreated, where there is a dependency action to keep their life, activities imposed by everyday ${ }^{(2,10)}$.

Describing the problems they experience reproduces speech of health professionals, which is based on a technical language repeating what was said without understanding what the technical term represents for their health ${ }^{(16)}$. This fact characterized the way to talk expressed in the statements such as fistula, depression, catheter and puncture.

So, it is inappropriately understood which is the fact of technically speaking. In gossiping "the talk can hide the meaning of things, permeated by median reproducing what was told, comprising according to their need or discomfort standing away from the original meaning"(14:105). The message they learn of the health team speech is if not perform the transplant something can happen, that is threatening and the same time liberating to associate transplantation as the link to return to life. They expressed by "you get with a lot of things, feels like an animal"; "only chance to live". 
In addition to gossiping, there was the bureaucracy expressed by hemodialysis days, the examinations for outpatient monitoring and to establish suitability for transplantation, the rating on the waiting list and the criteria for placement and ranking on the waiting list.

The being-there close to their possibilities and being in everyday life in the talk mode, the ambiguity, and curiosity shown in the "own way of being of everyday life which is the inauthenticity and impropriety"(14:179). Thus, the presence does not assume the health care, and it is guided by the other without having the power of decision and transferring their responsibility and their care.

In this way of being design the phenomenological time that "is the ability to be, to observe and to understand as possibilities being"(14:48). So, hemodialysis and the waiting list are experiences that permeate their existence after the discovery of kidney failure. This past is present and future for reporting: the first contact with the hemodialysis machine; the time of the sessions; and puncture of the arterial fistula. It evidence that today and tomorrow they will be on the waiting list and in the hemodialysis treatment till the possibility of renal transplantation, making a movement referring to the moment of experiences will not forget, in this their existence.

The hemodialysis being on the waiting list feels limited to rely on others. Before he was as common being. The "being-with is a determination of one's presence and also the co-presence when met the others, being liberating the possibility of being-there to being-there with others"(14:177). And in this movement, consider themselves hemodialysis beings in waiting list with family, friends and health professionals. They spoke of the things of their home, about small household chores, about socializing with: other people with chronic kidney disease; family members; health professionals; and the hemodialysis hospital/clinic ${ }^{(4)}$.

Therefore, we are in constant interaction with other beings-there, because we are all being-with- the-other. "This concern, in its essence, relates to the cure, i.e., the existence of the other is not a thing that is concerned, helps the other to become, in its healing, transparent and free" ${ }^{\text {(14:179). }}$.

In its way of being they are a being in daily life, in which "is all we talk, all we understand, how we behave in this or that way, being is also what it is as we are. Being is what it is and how it is" ${ }^{\prime 14: 42)}$. As beings living with other beings, and being like them in a deficient way, because they perceive only their physical aspects and forgetting the emotional aspects. And determining what they should do or should not do as: they can not drink liquids; should properly do the guidelines; they have to take medicine and go to hemodialysis ${ }^{(17)}$.

The hemodialysis being presents the curiosity when seeking knowledge about their disease and treatment, but at the same time disperses not to take the information supplied to them, "lying in a repeating cycle without questioning"(14:237). According to the testimonies is expressed negativity as the treatment, saying it is not good, but they need a routine not questioning about what it would take to improve and why the problem.

Thus, the hemodialysis being on the waiting list rests on the need for hemodialysis sessions, as a form of maintenance and survival, and the possibility of kidney transplantation as a means to improve their quality of life. As well as the protection of those who help in their care. The need to remain concerned is "the concern that, in essence, refers to the healing, i.e., the existence of the other is not a thing that is concerned, helps the other to become, in their healing, transparent and free" (14:179). However, for them, the safety of this care has a limit, though not express to the establishment, why is perceived physically and mentally weakened.

Thus, the being-there in everyday decides, accepts and assumes responsibility and the possibility of improving the maintenance of their life in conducting the dialysis while waiting for a kidney transplant. Thus, they engage in self-care making 
decisions about their health and disease as the position of performing the dialysis for survival; acceptance of waiting for a transplant; tend to improve their quality of life by accepting hemodialysis. Occupation with care is revealed as presence way for beings and not ontologically, unfolding-inauthentic to compare their organic functions with the hemodialysis machine, becoming an instrument to develop kidney function.

"The being-with in its existentialism must, in a presence way, to deal with things and worry about the other"(14:177). Thus, "this concern that, in its essence, is about healing, i.e., the existence of the other is not a thing that is concerned, helps the other to make the healing, transparent and free"(14:179).

In everyday, being-there appears impersonal to care, not to assume because do not decide about their health, being released on a day-by-day dialysis and waiting for a transplant. Thus, they have no control or knowledge about their ranking on the waiting list; and perform only the procedures, tests, protocols and certificates about their aptitude to belong to the waiting list for a possible kidney transplant ${ }^{(18)}$. Thus, heed the health team's decision and not from their needs and complaints. As Heidegger said, "Impersonal belongs to others and consolidates their power"(14:181).

\section{Conclusion}

The result of the research shows one facet of understanding of the person's everyday senses with chronic kidney disease on the waiting list for kidney transplantation, where the being-there presents in the world by inauthenticity and impersonality of their care, are disregarded in the subjective and unique aspects, becoming one of the several others.

It was verified the importance of understanding the person's everyday life the experience of waiting for a kidney transplant because their dependence on completion of hemodialysis and passively awaiting kidney transplantation, reflect in such a way that assumes their care and transfers its responsibility/ decision to someone else.

It is hoped that the study raises questions about how professional care can impact on the everyday lives of these people and the need for discussions about the interaction between health professionals and the person on hemodialysis. In this context arises the importance of nursing interaction as carefulbeing when searching their experiences, understand their needs, which can be related to pathology, as well as social, socioeconomic and cultural factors. Bringing the dialogue to change the inauthentic way to authenticate concerning health.

\section{Collaborations}

Cruz MRF contributed to the study design, analysis, data interpretation and writing of the article. Salimena AMO, Souza IEO and Melo MCSC contributed to the relevant critical review of the intellectual content of the article and approval of the version to be published.

\section{References}

1. Bastos MG, Bregman R, Kirsztajn GM. Doença renal crônica: frequente e grave, mas também prevenível e tratável. Rev Assoc Med Bras. 2010; 56(2):248-53.

2. Vann JC, Hawley J, Wegner S, Falk RJ, Harward DH, Kshirsagar AV. Nursing intervention aimed at improving self-managementfor persons with chronic kidney disease in North Carolina medicaid: a pilot project. Nephrol Nurs J. 2015; 42(3): 239-55.

3. Faria NV, Teixeira CMS, Nunes SFL. Users knowledge about the HIPERDIA program and chronic kidney disease. J Manag Prim Health Care. 2014; 5(1):4-9.

4. Oliveira MP, Soares AD. Percepciones de las personas con insuficiencia renal crónica sobre la calidad de vida. Enferm Glob. 2012; 11(28):25775 . 
5. Telles CT, Dobner T, Pomatti G, Fortes VF, Brock F, Bettinelli LA. Socio-demographic, clinical and laboratory profile of patients submitted to hemodialysis. Rev Rene. 2014; 15(3):420-6.

6. Oller GASAO, Ribeiro RCHM, Travagim DAS, Batista MA, Marques S, Kusumota L. Functional independence in patients with chronic kidney disease being treated with haemodialysis1. Rev Latino-Am Enfermagem. 2012; 20(6):1033-40.

7. Salimena AMO, Ferreira MR. Lista de espera para o transplante renal: revisão integrativa da literatura. Rev Arq Ciênc Saúde. 2014; 21(2):24-33.

8. Zanini MTB, Maragno F, Rosa L, Ceretta LB, Medeiros IS, Soratto MT, et al. A hemodiálise no cotidiano dos pacientes renais crônicos. Rev Inova Saúde Criciúma. 2012; 1(1):16-30.

9. Sadala MLA, Bruzos GAS, Pereira ER, Bucuvic EM. Patients' experiences of peritoneal dialysis at home: a phenomenological approach. Rev LatinoAm Enfermagem. 2012; 20(1):68-75.

10. Terra FS, Costa AMDD, Ribeiro CCS, Nogueira CS, Prado JP, Costa MD, etal. O portador de insuficiência renal crônica e sua dependência ao tratamento hemodialítico: compreensão fenomenológica. Rev Bras Clin Med. 2010; 8(4):306-10.

11. Salimena AMO, Chagas DNP, Melo MCSC, Soares TC, Magacho EJC. Sentimentos de mulheres frente à espera do transplante renal. Rev Enferm Brasil. 2010; 9(6):346-54.
12. Fontanella BJB, Luchesi BM, Saidel MGB, Ricas J, Turato ER, Melo DG. Amostragem em pesquisas qualitativas: proposta de procedimentos para constatar saturação teórica. Cad Saúde Pública. 2011; 27(2):389-94.

13. Ollaik LG, Ziller HM. Concepções de validade em pesquisas qualitativas. Educ Pesq. 2012; 38(1):229-41.

14. Heidegger M. Ser e tempo. Petrópolis: Vozes; 2012.

15. Paula CC, Souza IEO, Cabral IE, Padoin SMM. Analytical movement - Heideggerian hermeneutics: methodological possibility for nursing research. Acta Paul Enferm. 2012; 25(6):984-9.

16. Fernandes CCM. A estrutura ontológica da linguagem e a queda no falatório (Gerede) em Ser e Tempo. Peri [periódico na Internet]. 2015 [citado 2016 fev 20]; 7(2):136-47. Disponível em: http://www.nexos.ufsc.br/index.php/peri/ article/view/1060/557

17. Ribeiro CDS, Alencar CSM, Feitosa MCD, Mesquita MASB. Percepção do portador de doença renal crônica sobre o tratamento hemodialítico. Rev Interd. 2013; 6(3):36-44.

18. Souza AM, Filipini CB, Rosado SR, Dázio EMR, Fava SMCL, Lima RS. Kidney transplantation: experience of men in hemodialysis entered on the waiting list. Rev Rene. 2015; 16(1):11-20. 